\title{
THE AGRICULTURAL LANDSCAPE OF TEL BURNA: ECOLOGY AND ECONOMY OF A BRONZE AGE/IRON AGE SETTLEMENT IN THE SOUTHERN LEVANT
}

\author{
ANDREA ORENDI ${ }^{1}$, LADISLAV SMEJDA $^{2}$, CHRIS MCKINNY $^{3}$, \\ DEBORAH CASSUTO ${ }^{4}$, CASEY SHARP ${ }^{5}$ AND ITZICK SHAI ${ }^{6}$
}

\author{
${ }^{1}$ SFB 1070 "ResourceCultures”, Eberhard Karls Universität Tübingen, Gartenstr. 29, 72074 \\ Tübingen, GERMANY, e-mail: orendiandrea@hotmail.com \\ ${ }^{2}$ Department of Ecology, Czech University of Life Sciences Prague, Kamýcká 129, 16521 \\ Praha 6 - Suchdol, CZECH REPUBLIC \\ ${ }^{3}$ Texas A\&M University Corpus Christi, 6300 Ocean Dr, Corpus Christi, TX 78412, USA \\ ${ }^{4}$ Bar Ilan University, Ramat Gan, 5290002, ISRAEL \\ ${ }^{5}$ University of Haifa, 3498838, ISRAEL \\ ${ }^{6}$ The Institute of Archaeology, Ariel University, Israel; P.O.B. 3, Ariel 40700, ISRAEL
}

Received: $15^{\text {th }}$ May 2017, Accepted: $12^{\text {th }}$ September 2017

\begin{abstract}
The Shephelah, known as the breadbasket of the southern Levant, is one of the more extensively investigated regions of the southern Levant in terms of archaeobotanical research. However, studies dealing with agriculture are scarce in comparison to the archaeobotanical data available. The analysis of the archaeobotanical assemblage in combination with the archaeological remains from Tel Burna will contribute to the investigation of the agriculture of the Shephelah. Several seasons of excavation revealed a cultic complex dating to the Late Bronze Age and an Iron Age II settlement with various agricultural installations such as silos and wine or olive presses. In this paper, we present the agricultural features in conjunction with the systematical archaeobotanical sampling, which enables us to reconstruct the types of crop plants cultivated at the site. Grass pea seeds dominate the assemblage collected from the Late Bronze Age complex, which may point to a connection to the Aegean. The Iron Age assemblage is distinguished by a significantly broad range of crop plants which were cultivated in vicinity of the tell. The archaeological Iron Age remains indicate that the processing of secondary products such as olive oil, wine, or textiles took place within the Iron Age settlement of Tel Burna. This first comprehensive overview describes the character of agricultural production in the Late Bronze Age to Iron Age environmental and geopolitical transformations.
\end{abstract}

Keywords: Agriculture, Shephelah, Southern Levant, Iron Age, Late Bronze Age, Landscape

\section{INTRODUCTION}

As David and Thomas state, "landscapes are topographies of the social and the cultural as much as they are physical contours" (2008: 35). In this sense, this paper aims to investigate the agricultural landscape of Tel Burna not only from the archaeobotanical perspective but also from the sociocultural point of view. The investigation of the archaeobotanical material in collaboration 
with the material culture demonstrates how the agricultural landscape of Tel Burna is not restricted to the conventional meaning of this concept. Archaeobotanical macro remains are more than the mere relics of ecological or economic significance (Fairbairn, 2008: 448); as the interpretation of their presence in archaeological sites goes beyond their primary use as subsistence products (David \& Thomas, 2008: 36).

The archaeology of agriculture in the southern Levant has been the topic of many research studies (e.g., Borowski, 1987; Dever, 2012; King \& Stager, 2001; Zwickel, 2013). Notably, focus of these studies was limited to the archaeological finds and their contexts in combination with written sources. The actual object of research - the agricultural product - and its associated research field, namely Archaeobotany, have rarely been integrated into the general study of ancient agriculture in the southern Levant. ${ }^{1}$

Although the Shephelah is one of the more extensively investigated regions of the southern Levant in terms of archaeobotanical research, studies dealing with the topic agriculture, however, are scarce in comparison to the archaeobotanical data available. ${ }^{2}$ Exceptions can be seen in Salavert's (2008) research which takes a closer look at the cultivation of olive and olive oil processing at Tel Yarmuth during the Early Bronze Age. Kislev et al., (2006) present the data found at Tel Batash, which mainly focuses on the Late Bronze Age period.

The systematic archaeobotanical sampling at Tel Burna offers a great opportunity to combine the archaeological remains directly with the archaeobotanical data. First insights into the Iron Age agriculture and trade system at Tel Burna have been discussed in Riehl and Shai (2015). The present paper, however, is the first presentation of the complete archaeobotanical data from Tel Burna to be found thus far. It significantly complements the archaeobotanical data for the Iron Age Shephelah regarding the investigation of agriculture in this region. Restricted to the settlement areas of the tell and its vicinity, it appears that the surrounding lands were cultivated for various crop plants. Separating the Late Bronze and Iron Age data will enable us to determine the changes, or developments, of the agricultural landscape of Tel Burna, pertaining to crop management and the selection of crops throughout the periods. The Late Bronze Age assemblage reveals regional and interregional contacts. In contrast, the Iron Age data indicates what kind of crops would have been cultivated near the site. For this, the natural preconditions of the physical landscape are decisive criteria for intense agricultural activities. The archaeological remains of agricultural installations such as wine/olive presses, and finds such as silos and loom weights, complement the evidence of residues from the surrounding agricultural landscape of the tell. We synthesize all the available evidence to-date for the harvesting, the processing and the storage of basic agricultural produce and for primary as well as secondary consumption.

\footnotetext{
${ }^{1}$ Clearly, there are exceptions, e.g., Faust \& Weiss, 2005; Riehl \& Shai, 2015; Weiss et al., 2011.

${ }^{2}$ Tel Batash (Kislev et al., 2006), Hirbet er-Rasm (Weiss, 2011), Tel Yarmuth (Salavert, 2008), Giv'at Sharet (Mahler-Slasky \& Kislev, 2010), Lachish (Helbaek, 1958; Liphschitz, 2004; Liphschitz \& Waisel, 1975), Tell eș-Șāfĩ /Gath (Mahler-Slasky \& Kislev, 2012) and Tel Ḥalif (Laustrup \& Seger, 1990).
} 


\section{GEOGRAPHICAL AND ENVIRONMENTAL SETTING OF TEL BURNA}

Fig. 1: Location of Tel Burna

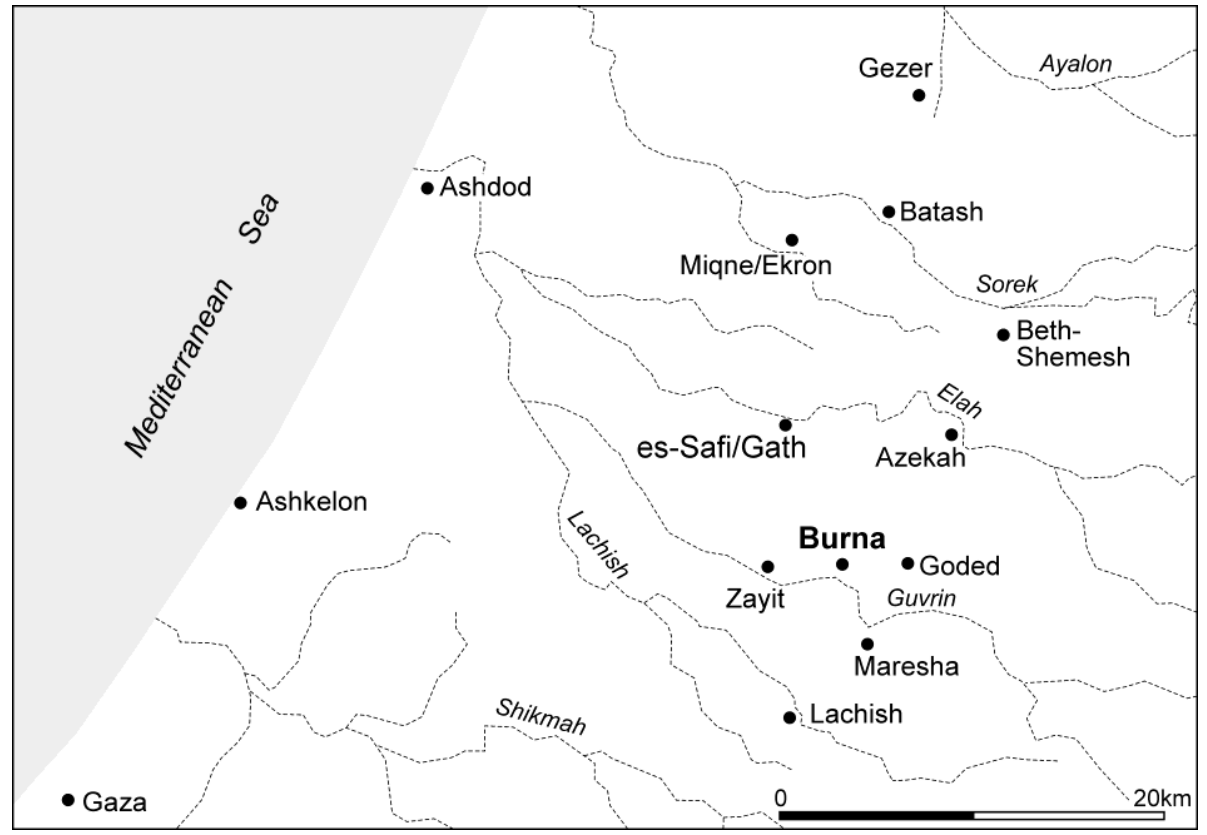

\section{Geopolitical Setting}

Tel Burna is located in the southern Shephelah on the northern banks of the Nahal Guvrin at the elevation of $248 \mathrm{~m}$ a.s.1. Throughout the Bronze and Iron Ages the Shephelah was a densely occupied region (e.g. Hardin, 2014: 743). During the Late Bronze Age the political organization in the southern Levant, in general, and in the Shephelah region in particular, was comprised of city-states. Somewhere around the turn of the first millennium B.C.E., territorial states were established and the area of Tel Burna became designated as the border between Judah to the east and the Philistine cities to the west. Thus far, the material culture of the Iron Age inhabitants at Tel Burna indicates a political affiliation with the Kingdom of Judah (Shai et al., 2012; Shai et al., 2015; Shai, 2017). Based on this interpretation, we expected to find a heavy destruction layer dating to the end of the $8^{\text {th }}$ century B.C.E. (Sennacherib's campaign to this region) ${ }^{3}$, however, as of yet, there is no indication for such a catastrophe at Tel Burna (Shai, 2017).

During the Iron Age, the site was situated between the two major cities of Tell eș-Șāfì/Gath and Lachish representing principle sites of Philistia and Judah respectively (Shai et al., 2012: 152; Shai, 2017: 45; Fig. 1). Located on the border between these two biblical opponents, the Judahite city could monitor the road along Nahal Guvrin, with a clear view of the Coastal/Philistine Plain to the west. Tel Burna has been tentatively identified as the biblical city Libnah mentioned in various verses in the Hebrew Bible/Old Testament (see e.g., 2 Kgs 8:22; also Josh 15:42, 10:29; 21:13). However, the identification remains debated as there has yet to be a consensus on the actual location of this biblical city (Shai et al., 2012: 143; Shai, 2017: 45-46).

\footnotetext{
${ }^{3}$ Many studies have focused on this Assyrian campaign. On its results and effects in the southern Levant see e.g., Ussishkin, 1977; 2006; Finkelstein \& Na'aman, 2004; Grabbe, 2003.
} 
Orendi A., Smejda L., McKinny Ch., Cassuto D., Sharp C., Shai I.: The agricultural landscape of Tel Burna: ecology and economy of a Bronze Age/Iron Age settlement in the Southern Levant

\section{Environmental setting}

The mean annual precipitation today in the southern Shephelah is between 400 and $500 \mathrm{~mm}$ distributed from October to May. The precipitation rate therefore provides an adequate water supply for rain-fed agriculture during winter and spring (Zohary, 1962: Map 3, Fig. 4). Moreover, the stream of Nahal Guvrin would provide sufficient water for manual irrigation if necessary (Riehl \& Shai, 2015: 526).

The tell is situated within the Mediterranean plant geographical vegetation zone (Currid, 1984: 2). The paleo-vegetation of the eastern lower Shephelah was once dominated by Evergreen Oak-Terebinth forests (Currid, 1984: Fig. 1). However, due to extensive land use, the area is now dominated by degraded Mediterranean garigue and batha vegetation with small trees and shrubs such as Ziziphus spina-christi. In the river valleys, savanna-like vegetation with grasses such as Hyparrhenia hirta is common (Currid, 1984: 5-6; Riehl \& Shai, 2015: 525; Zohary, 1962: 110-111, Map 5). The eastern and southern borders of the Mediterranean vegetation zone, which also fall into the region of Tel Burna, might be infiltrated by Irano-Turanian plant communities during drought periods (Olsvig-Whittaker et al., 2015: 59). Today, most parts of the Shephelah are still used as agricultural and grazing lands. In fact, the tell itself is part of an extensive grazing range for cattle (Smejda et al., 2017: 64, fig. 2d), whereas the southeastern plain below the tell along the nahal (a Hebrew equivalent for Arabic 'wadi') is agricultural land used for growing watermelons, cereals, sunflowers, and onions.

The southern Shephelah is mostly covered with brown and pale rendzinas, fertile soils suitable for the cultivation of different crops (Dan et al., 1976; Smejda et al., 2017: 45; Zohary, 1962: 11-12, Map 2). In her study of three nahals located south of Nahal Guvrin (Nahal Lachish, Nahal Adorayim, and Nahal Shiqma), Rosen (1986) identified several alluvial and erosional events. The two latest alluvial events, in the southern Shephelah, occurred during the Chalcolithic/Early Bronze Age period and during the Byzantine period. Although not included in Rosen's study, it should be assumed that such alluvial events, forming rich alluvial soils along the river beds, as well as the erosional events during drier time periods, likewise occurred in Nahal Guvrin.

According to studies of pollen remains, the Late Bronze Age IIB was struck by a short but intense drought period (Langgut et al., 2013: 160-61; Langgut et al., 2015: 229; Soto-Berelov et al., 2015: 107). However, studies conducted in the area of the Dead Sea indicate that the Late Bronze Age dry period had already begun around 1500 B.C.E. (Migowski et al,. 2006: 426; Kagan et al., 2015: 247). During the Iron Ages I and II, climate conditions tended to be slightly dry (Neumann et al., 2007: 1488, 1491, Kagan et al., 2015: 249; Migowski et al., 2006: 426). Notably, pollen records from cores taken along the Jordan Rift Valley indicate drier conditions during the Iron Age II rather than in the Iron Age I (Langgut et al., 2013: 157; Langgut et al., 2015: 229-230).

According to paleo-rainfall calculated by the $\delta^{18} \mathrm{O}$-isotopes from a speleothem from Soreq Cave, about $20 \mathrm{~km}$ north of Tel Burna, precipitation dropped through the Iron Age I (3200 BP) and slightly increased until the end of the Iron Age II (2500 BP). The range of calculated rainfall, however, spanned from 430 to $510 \mathrm{~mm}$ per year (Bar-Matthews \& Ayalon, 2004: Figure 12), still sufficient for rain-fed agriculture even during the drier periods. Rambeau (2010: 5230-33), however, observes that the data of the palaeo-climate proxies should be interpreted as local data. Problems of dating the proxies as well as various interpretation possibilities complicate a comprehensive paleo-climate study of supra-regional character.

Correspondence analyses of floral lists from various sites located in the Philistine Plain and the Shephelah show that the plant assemblages changed from mesic to xeric plants from the Late Bronze to the Iron Age. These results also indicate slightly drier conditions for the Iron Age than for the Late Bronze Age (Olsvig-Whittaker et al., 2015: 64-65, Fig. 5). Direct evidence of the water supply is given by the stable carbon isotope analysis of 50 barley grains from Tel Burna 
(Riehl \& Shai, 2015: 527-528). The grains were taken from an accumulation layer, and a silo, dating to the Iron Age IIB and IIC. The analysis of the stable carbon isotope shows that the barley grains had a sufficient water supply during the grain filling period, corresponding with the Iron Age II increase in precipitation identified in the $\delta^{18} \mathrm{O}$ from Soreq Cave (Riehl \& Shai, 2015: 530; Bar-Matthews \& Ayalon, 2004: Figure 12). While, it is not possible to directly link the $\delta^{13} \mathrm{C}$-values to precipitation values, the comparison to other ancient Near Eastern sites such as Qubur al-Walaydah, Tel Halaf, and Qatna indicates an ample water supply, either by natural precipitation or by artificial irrigation (Riehl \& Shai, 2015: 528, Fig. 3). In summary, the Lower Shephelah was more than suitable for intense agriculture. Water supply, either by precipitation or irrigation, as well as soil conditions (Fig. 3), should have enabled the cultivation of various crop plants.

\section{ARCHAEOLOGICAL RESEARCH}

In 2009, the Tel Burna Archaeological Project initiated a high-resolution survey of the site and its immediate surroundings (Uziel \& Shai, 2010). Subsequently, another survey method was applied, based on shovel test pits to further support the initial survey finds (Shai \& Uziel, 2014). Excavations commenced in 2010 and have continued since (Shai \& Uziel, 2014; Shai et al., 2015; Shai, 2017). Thus far, the material culture exposed dates to the Late Bronze IIB, the Iron IIA, IIB, and IIC. In addition, pottery finds from unstratified layers, from the survey results (Uziel \& Shai, 2010; Shai \& Uziel, 2014), and from Area C indicate human activity in the Early and Middle Bronze Age, the Iron Age I, the Persian and the Byzantine periods. To date, five excavation areas have been opened throughout the tell enabling the investigation of significant features including the fortifications surrounding the summit (Areas A1 and B2), the Iron Age II occupation upon the summit (Area A2), a public Late Bronze Age building on a shelf west of the summit (Area B1) and agricultural installations on the north-eastern slopes (Area C; Shai et al., 2012; Shai and Uziel 2014; Shai et al., 2015; Fig. 2). Prospection investigating the long-term human impact on the chemical composition of topsoil at the site and its vicinity started in 2015, bringing complementary data to archaeological survey and excavation campaigns (Smejda et al., 2017; Fig. 3). 
Fig. 2: Site plan of Tel Burna with the locations of all Areas

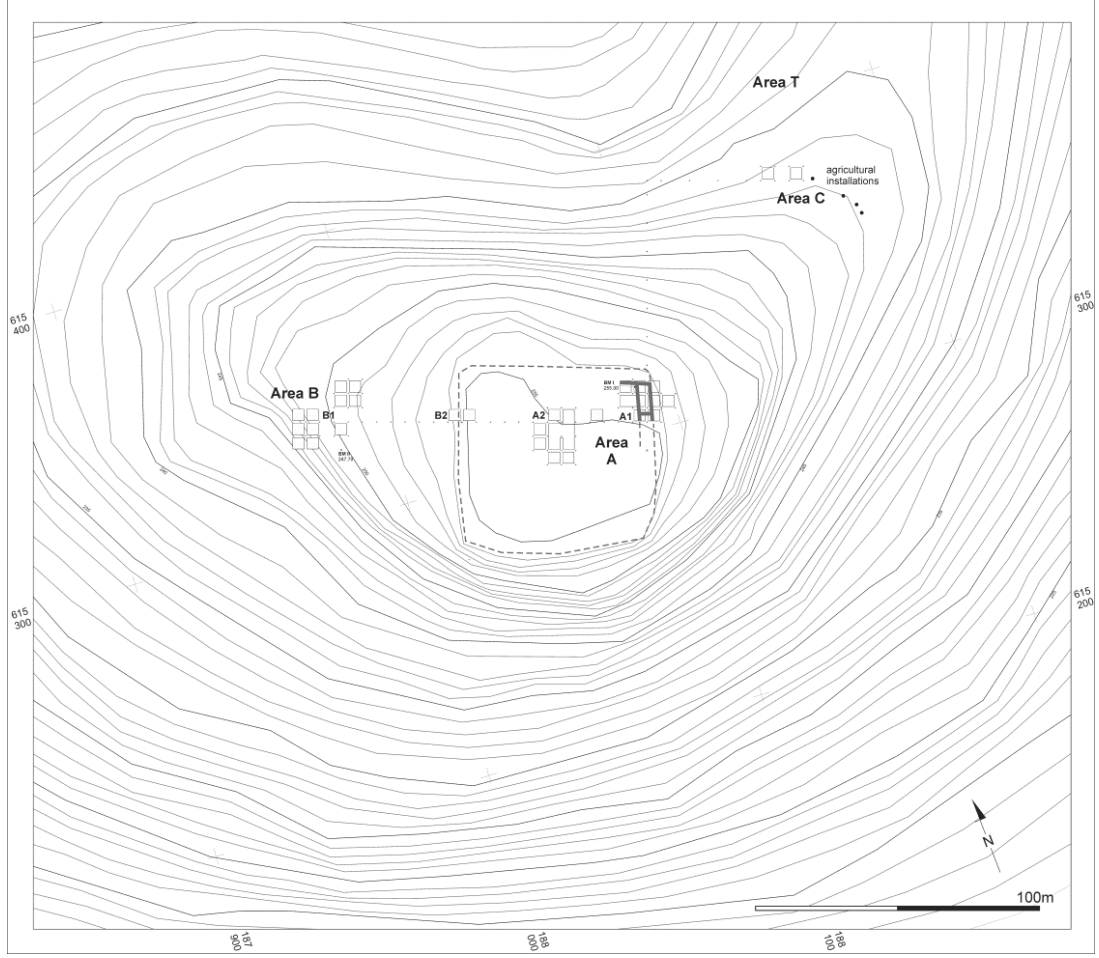

Fig. 3: Maps of selected nutrient concentrations in the contemporary topsoil around Tel Burna, resulting largely from ancient settlement activities and agricultural landscape management: a) Phosphorus, b) Potassium. Fertile soils were found in the close vicinity of the site that was fortified by a wall in the Iron Age (shown by the solid line enclosure). Interpolated values of our survey data $(\mathrm{N}=350)$ were divided into 4 classes by the quartile points. For details of the methodology used, see Smejda $e t$ al. 2017.
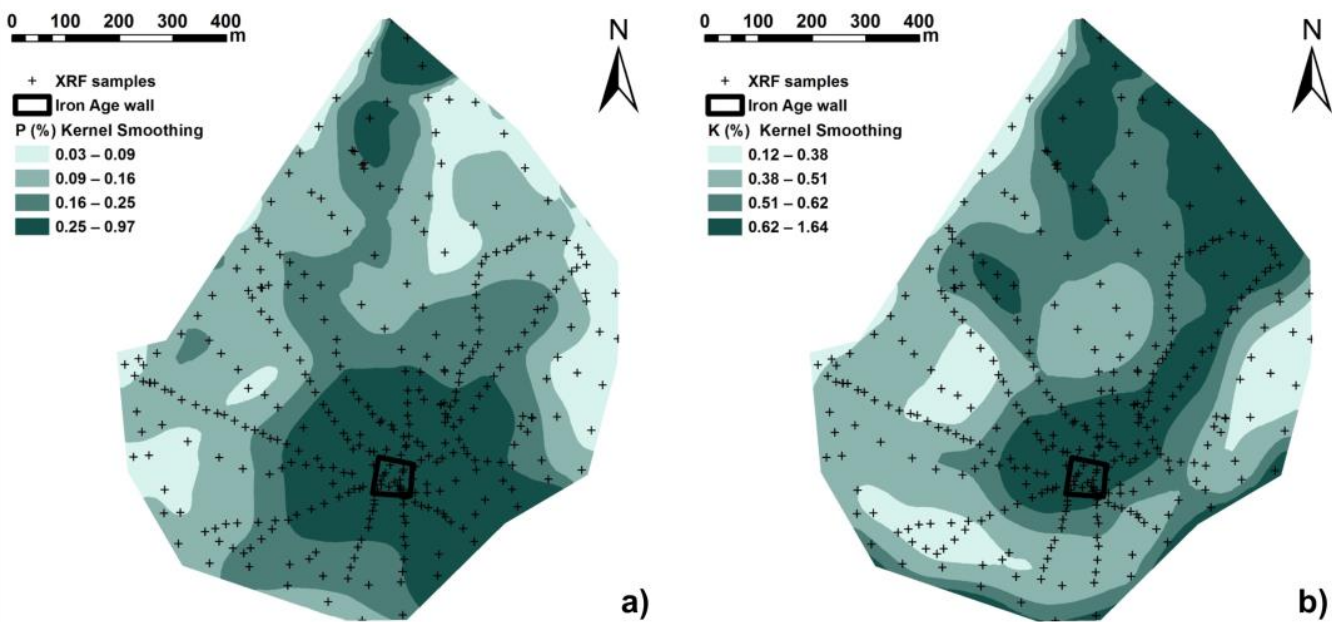


\section{MATERIALS AND METHODS}

Archaeobotanical sampling and flotation have been conducted continuously from 2011 to 2015 , collecting a total of 127 samples from the Late Bronze and Iron Age layers. Due to restricted time and a small-scale flotation device we decided to follow judgmental sampling. Various contexts have been sampled including ash layers, silos, accumulation layers, ovens (i.e., tabuns), etc. to retrieve as much information as possible. The sediment volumes of the samples vary between 0.5 and 601 , depending on the context, but most of the samples contained volumes of 301 . The sediment samples were processed using a flotation device with water recycling. The light fraction was collected in a $0.2 \mathrm{~mm}$ sieve and dried in cotton cloths. These samples were sent to the Archaeobotanical Laboratory of the Institute of Archaeological Sciences, University of Tübingen for further examination. The heavy residue was collected from a $1 \mathrm{~mm}$ mesh and, after drying, the heavy residues were roughly sorted for remaining botanical macro remains, faunal remains (i.e. small mammals and fish bones), and artifacts.

The archaeobotanical macro remains were sorted and identified using a binocular microscope with 10x magnification. The seeds and the charcoals were set aside separately. Identification of the charred seeds was conducted using the Tübingen-Senckenberg modern seed reference collection and additional identification resources, such as Nesbitt (2008), Jacomet (2006), and Neef et al. (2011).

Each complete seed was counted as one. Two halves or four quarters of fragmented cereals were added up to one seed. Other fragmented macro remains were also added up to one seed but only when preserved at least in halves. As for the interpretation of the archaeobotanical material, proportion and percentage ubiquity of the identified seeds were calculated. As this paper aims to provide a holistic view of the agricultural landscape of Tel Burna the following section connects the archaeobotanical data directly to the archaeological remains for each area. ${ }^{4}$

\section{RESULTS}

\section{The Late Bronze Age IIB}

\section{Area B1}

The architectural features found in Area B1 form a large structure (Building 29305), with several rooms and an inner courtyard (L33211) made of bedrock and crushed limestone. The bedrock fissures were filled with soil (Fig. 4; Shai et al., 2015: 117; Sharp et al., 2015: 61). The remains were only a few centimeters below surface level, and the Late Bronze Age sediment was only 20 to $120 \mathrm{~cm}$ thick before bedrock was reached (Shai et al., 2015: 117; Sharp et al., 2015: 61). The excavators maintain that the building was not of a domestic nature, due primarily to its impressive dimensions, of at least $20 \times 23 \mathrm{~m}$, and secondly to the technique by which it was constructed (Shai et al., 2015: 117-120). The surface sediment (L29105) of the courtyard revealed many animal bones and various pottery remains. Two ovens/tabuns were revealed in the courtyard: one (L29104) on the northeastern edge of the courtyard, a second oven/tabun (L53403) in the center of it. Moreover, next to the latter oven/tabun a row of sunken pithoi (two of them imported from Cyprus; Shai et al., 2015: 119) was discovered. The pottery included both locally produced vessels as well as Cypriot and Mycenaean imports in addition to numerous chalices, goblets, cup-and-saucer vessels, and a Cypriot triple-bowl votive vessel. Numerous figurines were found representing both local production (i.e., a Revadim-type figurine), imported Mycenaean and Cypriote zoomorphic figurines and an Egyptian influenced nude female plaque, as well as the nose fragments of two ceramic cultic masks (Sharp et al., 2015: 63-69). The character of these finds

\footnotetext{
${ }^{4}$ Area B2 will not be discussed as only one sample has been taken from this area thus far.
} 
Orendi A., Smejda L., McKinny Ch., Cassuto D., Sharp C., Shai I.: The agricultural landscape of Tel Burna: ecology and economy of a Bronze Age/Iron Age settlement in the Southern Levant

clearly implies that this building functioned as a center for cultic activities during the Late Bronze Age IIB (13 ${ }^{\text {th }}$ century B.C.E.; Shai et al., 2015: 117).

Although a wide variety of contexts were sampled in this area (40 samples; Table 1), the archaeobotanical remains - with a total count of 541 macro remains - in general were scarce. The majority of seeds derive from two samples taken from a layer of smashed vessels in situ. This layer stretched along the western wall (W43105) of the building next to the courtyard. Amongst these vessel fragments about 370 charred seeds of grass pea (Lathyrus sativus; $68.4 \%$; Fig. 5; Table 1) were found, which were likely to have been stored inside the broken vessels. The preservation of the grass pea seeds was quite good, the majority were found as whole cotyledons, only single seeds were split into halves.

\section{Fig. 4: Image of Area B1 with some features and finds marked}

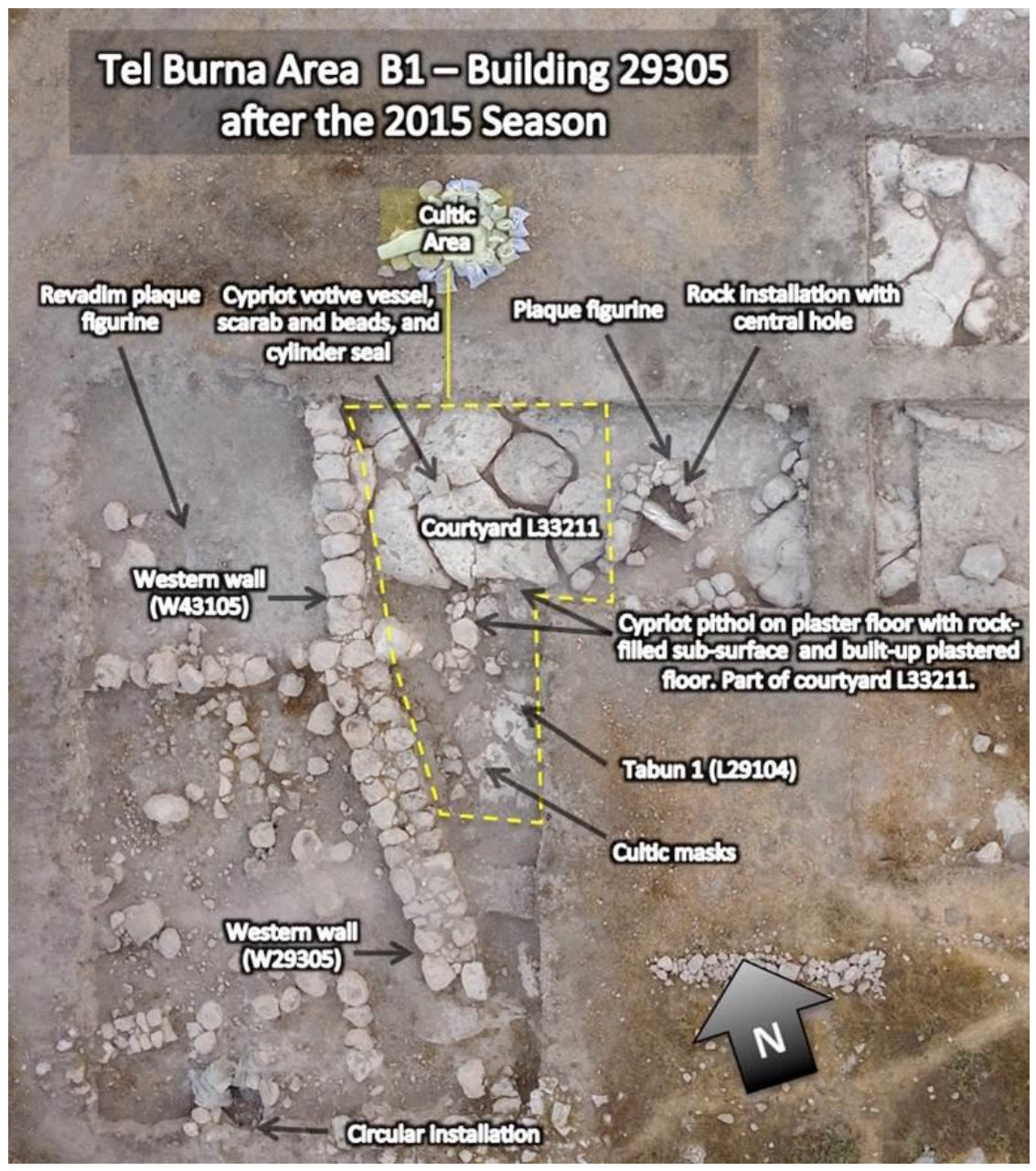


Table 1: List of taxa found at Tel Burna separated by the Areas B1, A1, A2, and C. Data is presented in percentage proportion (\%) and percentage ubiquity $(U)$. For the wild taxa only the most ubiquitous and numerous taxa are mentioned.

\begin{tabular}{|c|c|c|c|c|c|c|c|c|}
\hline Area & & \multicolumn{2}{|c|}{ Area B1 } & \multicolumn{2}{|c|}{ Area A1 } & \multicolumn{2}{|c|}{ Area A2 } & Area C \\
\hline Period & & \multicolumn{2}{|c|}{ Late Bronze Age IIB } & \multicolumn{2}{|c|}{ Iron Age IIA-IIC } & \multicolumn{2}{|c|}{ Iron Age IIA-IIC } & $\begin{array}{l}\text { Late Bronze } \\
\text { and Iron Age }\end{array}$ \\
\hline Number of samples & & \multicolumn{2}{|c|}{40} & \multicolumn{2}{|c|}{25} & \multicolumn{2}{|c|}{59} & 4 \\
\hline Volume in I & & \multicolumn{2}{|c|}{590} & \multicolumn{2}{|c|}{670} & \multicolumn{2}{|c|}{878.5} & 100 \\
\hline Total count of seeds & & \multicolumn{2}{|c|}{541} & \multicolumn{2}{|c|}{451} & \multicolumn{2}{|c|}{2284} & 20 \\
\hline Cultigens & Common Name & $\%$ & $\mathbf{U}$ & $\%$ & $\mathbf{U}$ & $\%$ & $\mathbf{U}$ & $\%$ \\
\hline Coriandrum sativum & Coriander & 0.0 & 0 & 0.0 & 0 & 0.0 & 2 & 0 \\
\hline Lens culinaris & Lentil & 0.2 & 2.5 & 1.3 & 16 & 0.4 & 10 & 0 \\
\hline Lathyrus sativus & Grass Pea & 68.4 & 5 & 0.0 & 0 & 0.1 & 3 & 0 \\
\hline Lathyrus sp. & Vetchling & 0.0 & 0 & 0.0 & 0 & 0.1 & 3 & 0 \\
\hline Lathyrus sp./Vicia sp. & Vetchling/Vetch & 0.0 & 0 & 0.0 & 0 & 0.5 & 8 & 0 \\
\hline cf. Pisum sativum & Common Pea & 0.0 & 0 & 0.0 & 0 & 0.2 & 8 & 0 \\
\hline Vicia cf. faba & Broad Bean & 0.0 & 0 & 0.0 & 0 & 0.1 & 3 & 0 \\
\hline Vicia ervilia & Bitter Vetch & 0.2 & 2.5 & 1.5 & 20 & 0.7 & 17 & 0 \\
\hline $\begin{array}{l}\text { Legumes cultivated, } \\
\text { indet. }\end{array}$ & Legumes & 0.9 & 10 & 3.7 & 36 & 1.1 & 36 & 15 \\
\hline Linum usitatissimum & Flax & 0.0 & 0 & 1.5 & 28 & 3.4 & 17 & 0 \\
\hline Punica granatum & Pomegranate & 0.4 & 2.5 & 0.0 & 0 & 0.04 & 2 & 0 \\
\hline Ficus carica & Fig & 3.1 & 25 & 2.2 & 36 & 18.3 & 58 & 0 \\
\hline Olea europaea & Olive & 1.7 & 22.5 & 1.7 & 24 & 4.2 & 64 & 0 \\
\hline Hordeum vulgare & Barley & 0.2 & 2.5 & 2.6 & 36 & 4.9 & 22 & 0 \\
\hline cf. Hordeum vulgare & Barley & 0.2 & 2.5 & 0.2 & 4 & 0.1 & 3 & 10 \\
\hline Hordeum vulgare, rachis & Barley, chaff & 0.2 & 2.5 & 0.6 & 4 & 0.1 & 5 & 0 \\
\hline $\begin{array}{l}\text { Hordeum vulgare ssp. } \\
\text { distichon, rachis }\end{array}$ & $\begin{array}{l}\text { Two-Row Barley, } \\
\text { chaff }\end{array}$ & 0.4 & 2.5 & 0.0 & 0 & 0.0 & 0 & 0 \\
\hline Triticum sp. & Wheat & 0.0 & 0 & 0.9 & 16 & 2.8 & 17 & 0 \\
\hline Triticum dicoccum & Emmer Wheat & 0.0 & 0 & 0.4 & 8 & 0.6 & 8 & 0 \\
\hline $\begin{array}{l}\text { Triticum } \\
\text { dicoccum/monococcum }\end{array}$ & Glume Wheat & 0.0 & 0 & 0.0 & 0 & 0.0 & 2 & 0 \\
\hline $\begin{array}{l}\text { Triticum } \\
\text { dicoccum/monococcum, } \\
\text { spikelet }\end{array}$ & $\begin{array}{l}\text { Glume Wheat, } \\
\text { chaff }\end{array}$ & 0.0 & 0 & 0.6 & 12 & 0.1 & 3 & 0 \\
\hline $\begin{array}{l}\text { Triticum } \\
\text { dicoccum/monococcum, } \\
\text { glume base }\end{array}$ & $\begin{array}{l}\text { Glume Wheat, } \\
\text { chaff }\end{array}$ & 0.0 & 0 & 0.0 & 0 & 0.2 & 3 & 0 \\
\hline Triticum durum/aestivum & $\begin{array}{l}\text { Free Threshing } \\
\text { Wheat }\end{array}$ & 0.0 & 0 & 0.7 & 12 & 0.2 & 8 & 0 \\
\hline
\end{tabular}


Orendi A., Smejda L., McKinny Ch., Cassuto D., Sharp C., Shai I.: The agricultural landscape of Tel Burna: ecology and economy of a Bronze Age/Iron Age settlement in the Southern Levant

\begin{tabular}{|c|c|c|c|c|c|c|c|c|}
\hline Cerealia & Cereals & 2.8 & 17.5 & 9.1 & 68 & 11.5 & 46 & 20 \\
\hline Cerealia, culm & Cereals & 0.2 & 2.5 & 0.0 & 0 & 0.0 & 2 & 0 \\
\hline Vitis vinifera & Grape & 2.0 & 22.5 & 0.7 & 12 & 3.9 & 41 & 0 \\
\hline $\begin{array}{l}\text { Vitis vinifera, } \\
\text { undeveloped pip }\end{array}$ & Grape & 0.0 & 0 & 0.0 & 0 & 0.3 & 10 & 0 \\
\hline Vitis vinifera, fruit & Grape & 0.2 & 2.5 & 0.0 & 0 & 0.1 & 3 & 0 \\
\hline \multicolumn{9}{|c|}{ Most ubiquitous wild species } \\
\hline $\begin{array}{l}\text { Ornithogalum } \\
\text { sp./Muscari sp. }\end{array}$ & $\begin{array}{l}\text { Star of } \\
\text { Bethlehem/Grape } \\
\text { Hyacinth }\end{array}$ & 0.0 & 0 & 0,0 & 0 & 2.0 & 12 & 0 \\
\hline $\begin{array}{l}\text { Lithospermum cf. } \\
\text { tenuiflorum, mineralized }\end{array}$ & Stoneseed & 2.0 & 15 & 46.8 & 72 & 13.1 & 15 & 5 \\
\hline Vaccaria pyramidata & Cow Cockle & 0.2 & 2.5 & 0.0 & 0 & 2.1 & 14 & 0 \\
\hline Chenopodium sp. & Goosefoot & 0.4 & 5 & 0.0 & 0 & 0.4 & 10 & 0 \\
\hline Cuscuta sp. & Dodder & 0.6 & 7.5 & 1.3 & 8 & 1.4 & 17 & 0 \\
\hline Medicago sp. & Snail Clover & 0.2 & 2.5 & 0.6 & 8 & 3.5 & 19 & 0 \\
\hline Trifolium sp. & Trefoil & 3.3 & 35 & 0.0 & 0 & 3.8 & 37 & 10 \\
\hline Malva sp. & Mallow & 0.4 & 5 & 0.2 & 4 & 2.0 & 20 & 0 \\
\hline Lolium sp. & Darnel Grass & 4.3 & 22.5 & 0.7 & 12 & 8.1 & 41 & 0 \\
\hline Phalaris sp. & Canary Grass & 0.9 & 10 & 0.4 & 8 & 1.1 & 22 & 0 \\
\hline Poaceae & Wild Grasses & 2.4 & 20 & 4.1 & 48 & 2.0 & 36 & 15 \\
\hline Anagallis sp. & Pimpernel & 0.0 & 0 & 0.7 & 12 & 0 & 0 & 0 \\
\hline Thymelaea sp. & Thymelaea & 0.0 & 0 & 0.4 & 8 & 0.3 & 12 & 10 \\
\hline
\end{tabular}

\section{Fig. 5: Image of Lathyrus sativus seeds from Area B1}

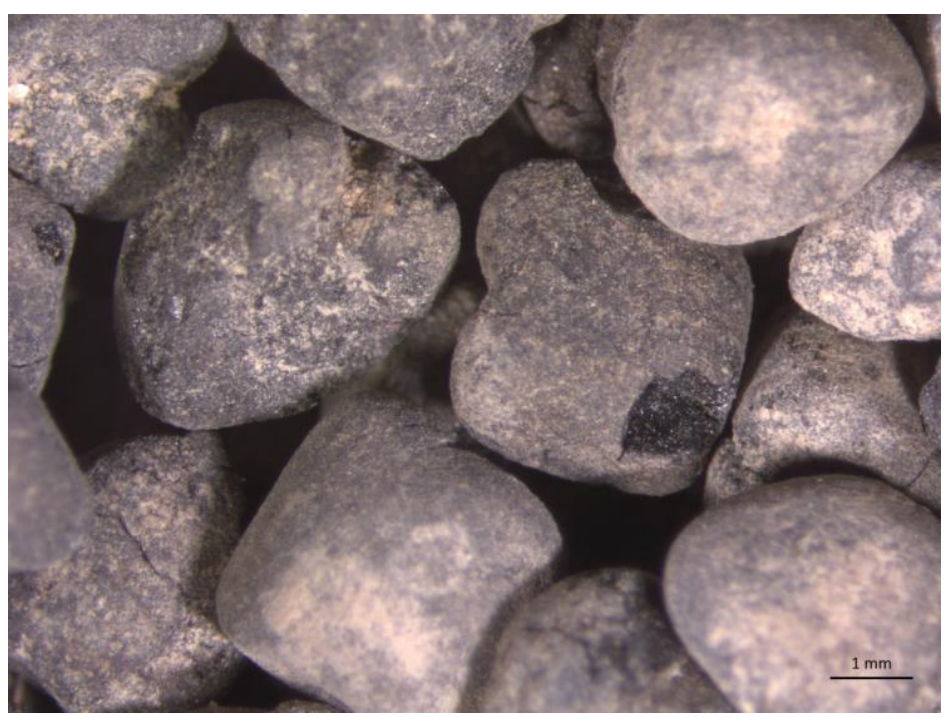


The remaining archaeobotanical Late Bronze Age macro remains are scarce (Table 1). The preservation of the charred seeds is poor and they are mostly represented by wild species such as darnel grass (Lolium sp.; $4.3 \%$ ) and trefoil (Trifolium sp.; $3.3 \%$ ), which are indicators of segetal and pasture vegetation (Zohary, 1962: 215, 221-225). Crops are hardly represented with single finds of barley, unidentifiable cereals, fig, olive, grape, lentil, and bitter vetch.

\section{The Iron Age II}

Throughout the Iron Age II, Tel Burna was part of the Kingdom of Judah (Shai, 2017). During this period, the settlement was not limited to the summit of the tell, but had apparently spread beyond the fortification walls and encompassed the southern, northern and eastern slopes as well. To date, excavations focused on the summit (Areas A1 and A2) and have exposed Iron Age occupation dating to the $9^{\text {th }}$ through the $7^{\text {th }}$ centuries B.C.E. ${ }^{5}$ Thus far, the main occupation stratum uncovered dates to the Iron Age IIB ( $8^{\text {th }}$ century B.C.E.; Shai et al., 2012; Shai, 2017).

\section{Area A1}

A square-shaped fortification wall enclosing an area of about $70 \times 70 \mathrm{~m}$ surrounded the summit. This wall was of the casemate type with two parallel walls (W13002 and W12006) situated about $2 \mathrm{~m}$ apart and connected with perpendicular walls (W21206; Fig. 6; Shai et al., 2012: 144). ${ }^{6}$

\section{Fig. 6: Site plan of Area A1}

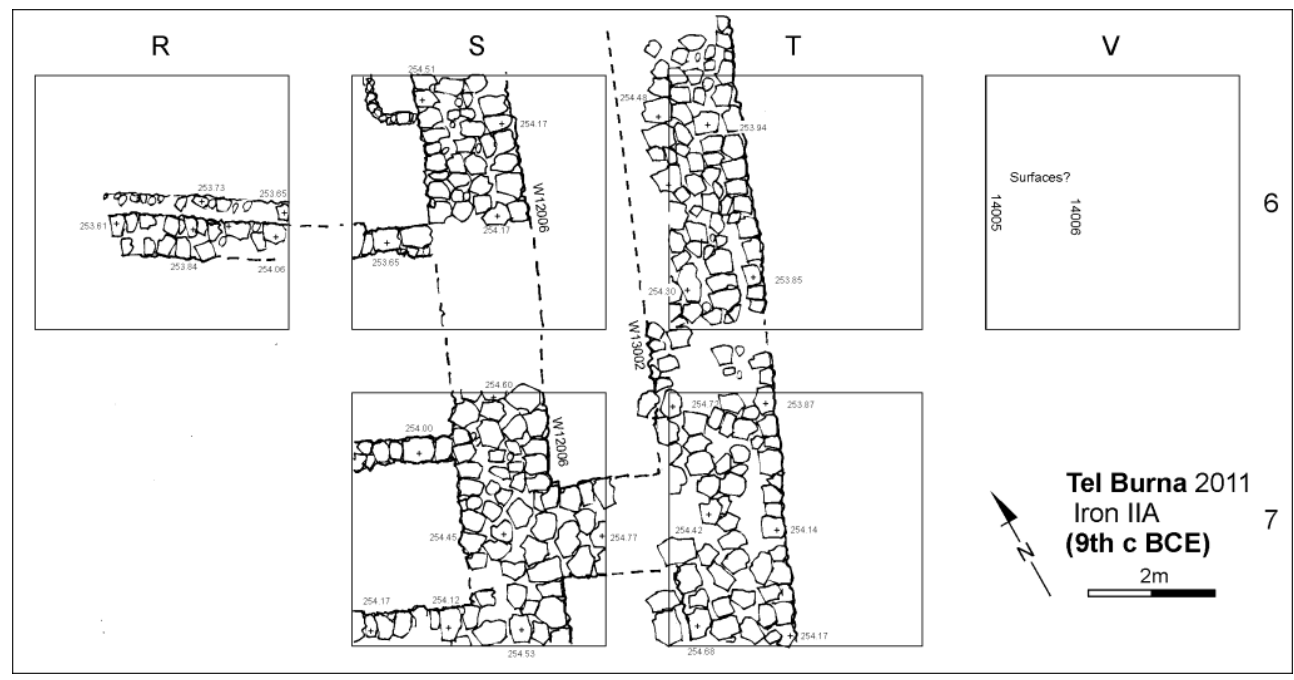

Based on associated pottery finds, the earliest evidence for this casemate wall dates from the $9^{\text {th }}$ through the $8^{\text {th }}$ century B.C.E. ${ }^{7}$ During the $7^{\text {th }}$ century B.C.E., a silo (W12007; Shai et al., 2012: 127) was built into the northwestern casemate fortifications cutting the inner wall. Therefore, it is clear that at least the inner wall was not in use by the time the silo had been constructed, however, the status of the outer wall during the Iron Age IIC is still unclear. Notably, this was one of

\footnotetext{
${ }^{5}$ With ceramic indicators of pre- $9^{\text {th }}$ century B.C.E. Iron IIA occupation found in both the surveys and the excavations in Area A1 and A2.

${ }^{6}$ Only one such connecting wall has been exposed in this area due to limited excavation exposure along the insides of the fortifications.

${ }^{7}$ Since the foundations of the fortification walls have not yet been exposed, it may even have been constructed earlier than the $9^{\text {th }}$ century B.C.E.
} 
Orendi A., Smejda L., McKinny Ch., Cassuto D., Sharp C., Shai I.: The agricultural landscape of Tel Burna: ecology and economy of a Bronze Age/Iron Age settlement in the Southern Levant

numerous silos constructed during the Iron Age IIC, disturbing the architectural remains of the Iron Age IIB stratum in both Areas A1 and A2.

The 25 archaeobotanical samples from Area A1 (Table 1) were mostly collected from the excavation of four silos. In general, the successful recovery of seeds was very low with less than 60 seeds per sample. The assemblage is clearly dominated by wild species with close to $50 \%$ of stoneseed (Lithospermum cf. tenuiflorum syn. Buglossoides tenuiflora; Fig. 7) which was also present in three-quarters of the samples (ubiquity of $72 \%$; Table 1). The stoneseed remains were mineralized. The fruits of Lithospermum-plants accumulate calcium carbonate, which derives from the sediments and soils in which they were preserved (Pustovoytov \& Riehl, 2006: 508). The seeds have yet to be radiocarbon-dated (Pustovoytov \& Riehl, 2006), thus, it remains unclear whether they were deposited in the Iron Age or are modern contaminants. In contrast, all other archaeobotanical remains from the Iron Age samples were preserved in carbonized state. In general, the preservation of seeds and fruits was poor, as most of the seeds were fragmented. In addition, most of the seed's outer coats were eroded so that a distinct identification of species level was not possible.

Fig. 7: SEM image of a mericarp from Lithospermum cf. tenuiflorum (from layer 42409, Area A2)

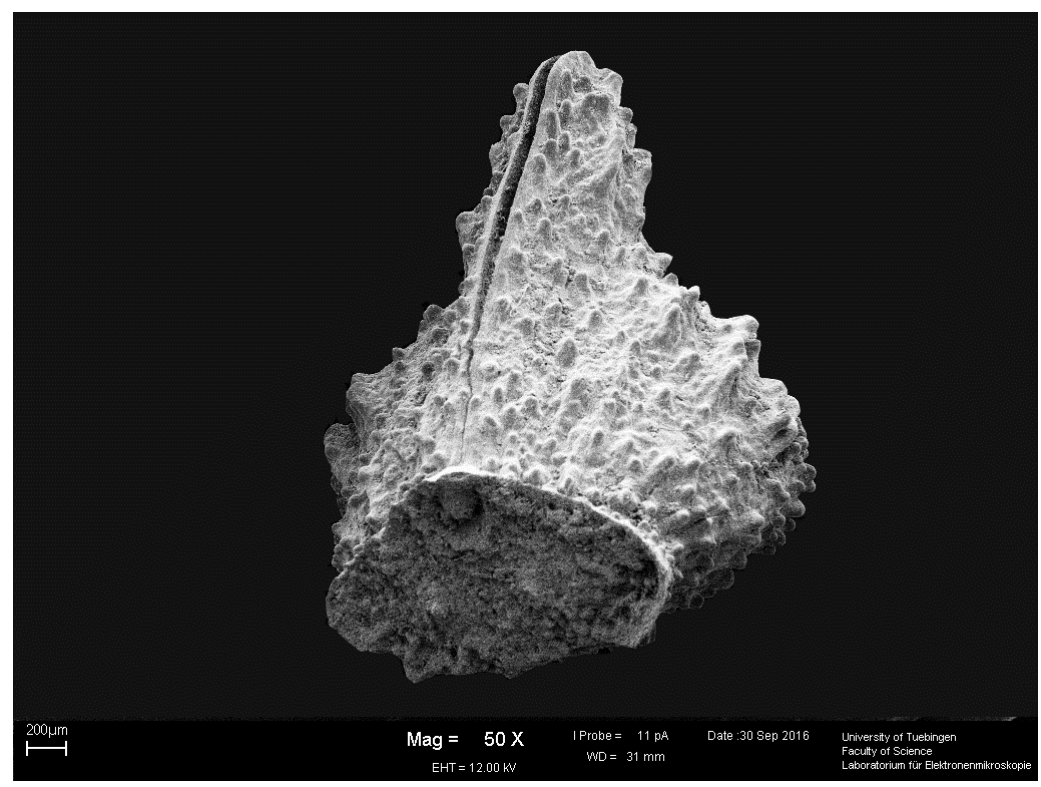

Some other wild taxa were found in lower quantities such as snail clover (Medicago sp.; $0.6 \%$ ), wild grasses (Poaceae; $4.1 \%$ ), darnel grass (Lolium sp.; $0.7 \%$ ), and pimpernel (Anagallis sp.; $0.7 \%$ ). Most of these grow in open vegetation, while some of them are field weeds (Lolium sp. and Anagallis sp.), whereas the stoneseed plants grow in stony places (Riehl, 2010: Table 4).

In contrast to the wild plant remains, the crops were found in low quantities (Table 1). They are mostly represented by various cereal grains of barley $(2.8 \%)$, different wheat species consisting of emmer wheat (Triticum dicoccum; $0.4 \%)$ and free threshing wheat $(0.7 \%)$. Yet, most of the cereal grains (Cerealia; $9.1 \%$ with a ubiquity of $68 \%$ ) could not be identified even to genus level, due to the poor preservation of the macro remains. Chaff remains of barley were low in number $(0.6 \%)$ compared to the grain finds. Lentil (Lens culinaris; $1.3 \%$ ) and bitter vetch (Vicia ervilia; $1.5 \%$ ) 
were the only legumes found next to a higher amount of unidentifiable cultivated legumes $(3.7 \%)$. The macro remains from fruits are represented by olive (Olea europaea; $1.7 \%$ ), fig (Ficus carica; $2.2 \%$ ) and grape (Vitis vinifera; $0.7 \%$ ), the typical Mediterranean fruit species grown in the southern Levant. Finds of flax (Linum usitatissimum; $1.5 \%$; Fig. 8) were numerous compared to the general distribution of this plant in the southern Levant (Riehl \& Shai, 2015: 528). The seeds of the dodder plant (Cuscuta sp.; $1.3 \%$; Fig. 9) indicate the cultivation of flax, as Cuscuta epilinum, the flax dodder, is a typical weed of cultivated flax plants (Feinbrun-Dothan, 1978: 47).

Fig. 8: SEM image of a seed of Linum usitatissimum (from ash layer 62213, Area A2)

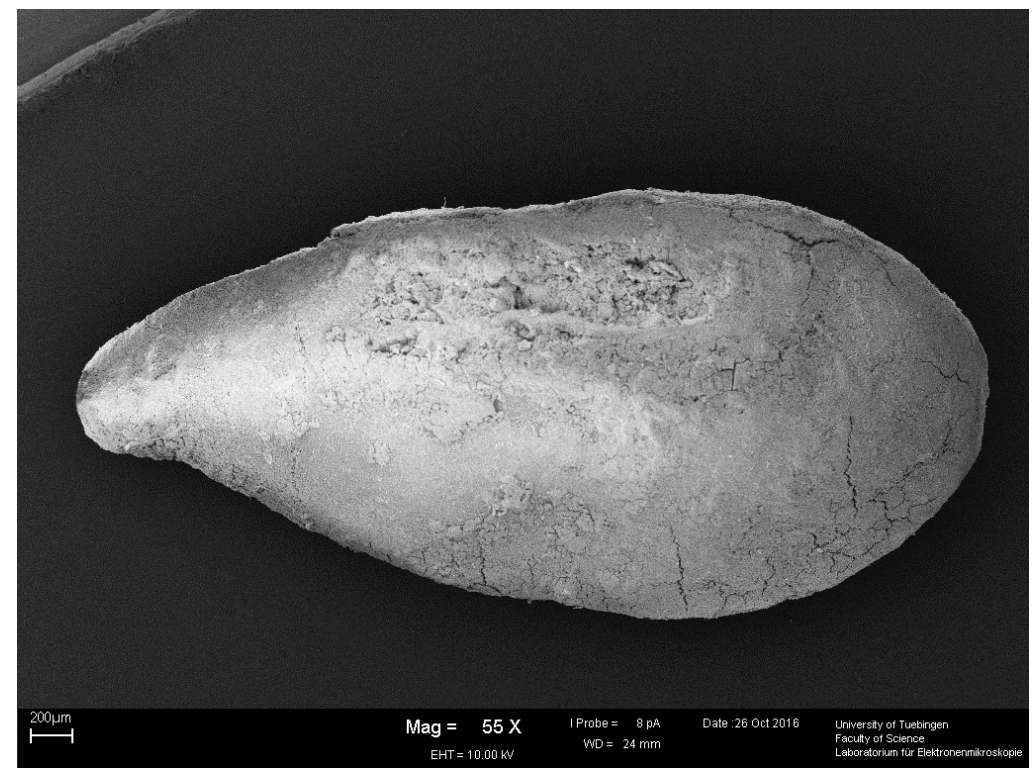

Fig. 9: SEM image of a seed of Cuscuta sp. (from silo 32105, Area A2)

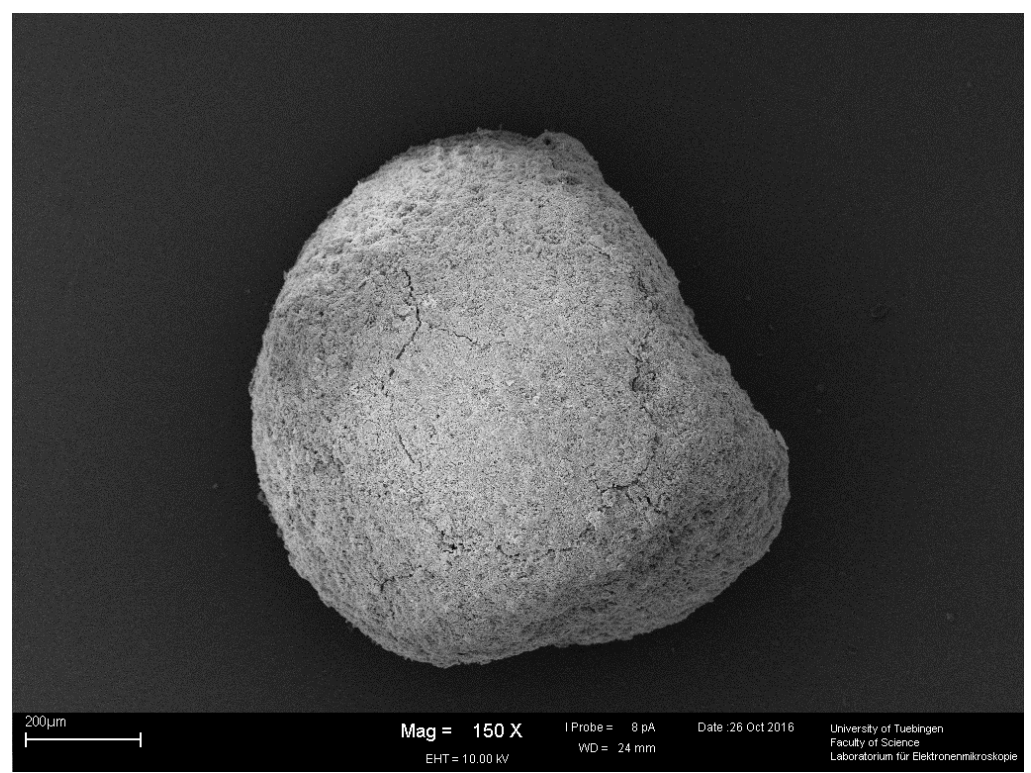


Orendi A., Smejda L., McKinny Ch., Cassuto D., Sharp C., Shai I.: The agricultural landscape of Tel Burna: ecology and economy of a Bronze Age/Iron Age settlement in the Southern Levant

\section{Area A2}

The excavations revealed a large building (Building, 52008) with two monolithic pillars and a paved courtyard (L25404; Fig. 10). This open courtyard located north of the building revealed more than 30 loom weights found on the floor in situ.

\section{Fig. 10: Site plan of Area A2}

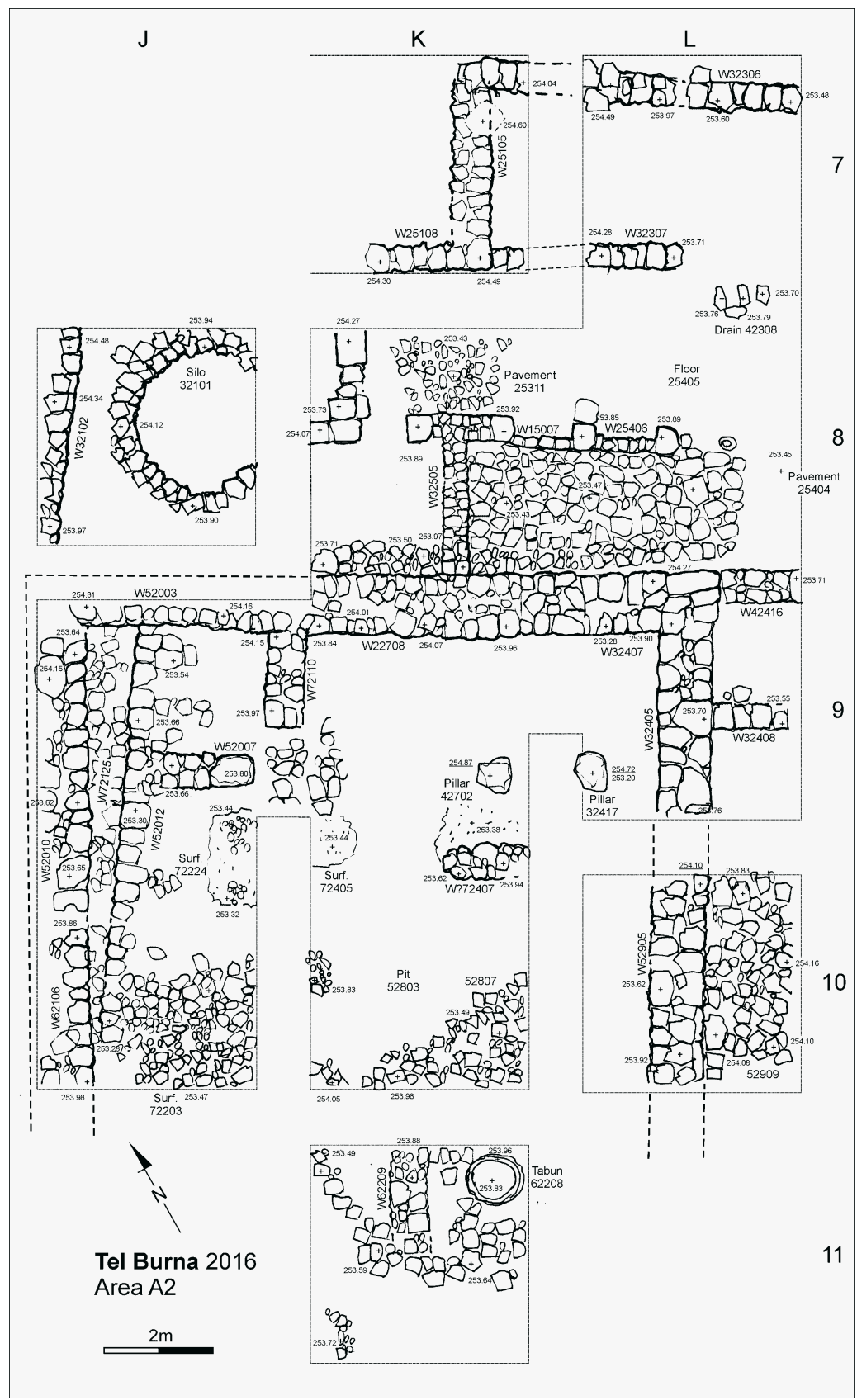


The finds date the main occupation of this building complex to the Iron Age IIB $\left(8^{\text {th }}\right.$ century B.C.E.). The interior of the building was covered with a beaten-earth floor. One room (R52006) contained vessels also found in situ. While it is tempting to correlate the end of the Iron Age IIB settlement ( $8^{\text {th }}$ century B.C.E.) with Sennacherib's campaign, the lack of a clear destruction layer is surprising (Shai, 2017: 50). During the $7^{\text {th }}$ century B.C.E. (Iron Age IIC), a new occupation phase is attested reusing some of the architectural remains of the Iron Age IIB occupation and three more round-shaped silos dug into the Iron Age IIB remains (Riehl \& Shai, 2015: 526; Shai, 2017: 50-52).

Samples were collected from several contexts, including the fill of silos, ash layers, floor accumulation layers, debris layers, and pottery accumulations. The 59 samples (Table 1) revealed the highest number of macro remains from Tel Burna, which were mostly carbonized. However, most of the samples contained less than 50 seeds. Only three contexts provided the most macro remains from Area A2: an accumulation layer (L42409; Sq. L9) within a room of the building, another accumulation layer (L32208, Sq. K7; both dating to the Iron Age IIB), and a large silo (sediment layers 32103, 32105, 32106, 32107; Sq. J8) with a diameter of appr. $3.5 \mathrm{~m}$ dating to the Iron Age IIC.

The proportion of cultigens and wild species is almost balanced with a slight prevalence for crop species. The variety of cultigens from this area is diverse. The legumes were mostly lentil $(0.4 \%)$, vetches/vetchlings (Vicia sp./Lathyrus sp. 0.5\%), bitter vetch (Vicia ervilia; $0.7 \%$ ), and unidentifiable legumes $(1.1 \%)$. The charred cereals were not very well preserved, and most of the remains $(11.5 \%)$ could not even be identified to genus level. However, some grains of barley (Hordeum vulgare; $5.0 \%$ ), wheat (Triticum sp.; $2.8 \%$ ), emmer wheat (Triticum dicoccum; $0.6 \%$ ), and free threshing wheat (Triticum durum/aestivum; $0.2 \%$ ) were found. Chaff remains from barley $(0.1 \%)$ and glume wheat $(0.3 \%)$ were scarce. Fruits are represented by grape remains $(4.3 \%)$, as well as olive $(4.2 \%)$, pomegranate (Punica granatum; $0.04 \%)$, and many fig seeds $(18.3 \%)$. Moreover, olive and fig also show a vast distribution throughout Area A2 with a ubiquity of $64 \%$ and $58 \%$. In comparison to Area A1, despite being higher in number, finds of linseeds $(3.4 \%)$ were quite numerous.

The wild species are dominated by stoneseed $(13.1 \%)$ and darnel grass $(8.1 \%)$. The mineralized mericarps of the stoneseed plants were mostly found associated with an accumulation of pottery sherds from a vessel embedded in one of the accumulation layers (L42409) mentioned above. The most ubiquitous wild species, next to stoneseed and darnel grass, are Ornithogalum sp./Muscari sp., Cuscuta sp., Trifolium sp., Vaccaria pyramidata, Chenopodium sp., Anagallis sp., Malva sp., Thymelaea sp., Phalaris sp., and wild grasses, all of which grow in open vegetation (Riehl 2010: Table 4). Among the above-mentioned wild taxa, there are typical field weeds like darnel grass, mallow, cow cockle, and pimpernel (Zohary 1962: 221-225).

\section{Area C}

Area C was opened in 2015 on the eastern slopes of the tell (Fig. 11). It is located in an area which is densely covered with agricultural installations cut into the exposed bedrock. The installations appear to have functioned as wine or olive presses, but other uses are possible. Installations in this area vary greatly in size and shape, and it is likely that some may have had divergent functions during the various occupations of the site. In addition, more storage pits and basins are to be found along the eastern slope (Smejda et al., 2017: 64). Basalt grinding stones and flint artifacts substantiate the area's agricultural activities. The pottery found in Area C, including within the installations themselves, dates from the Early and Middle Bronze Ages, in addition to the Late Bronze II and Iron Ages attested to in the other excavation areas. 
Fig. 11: Site plan of Area $C$

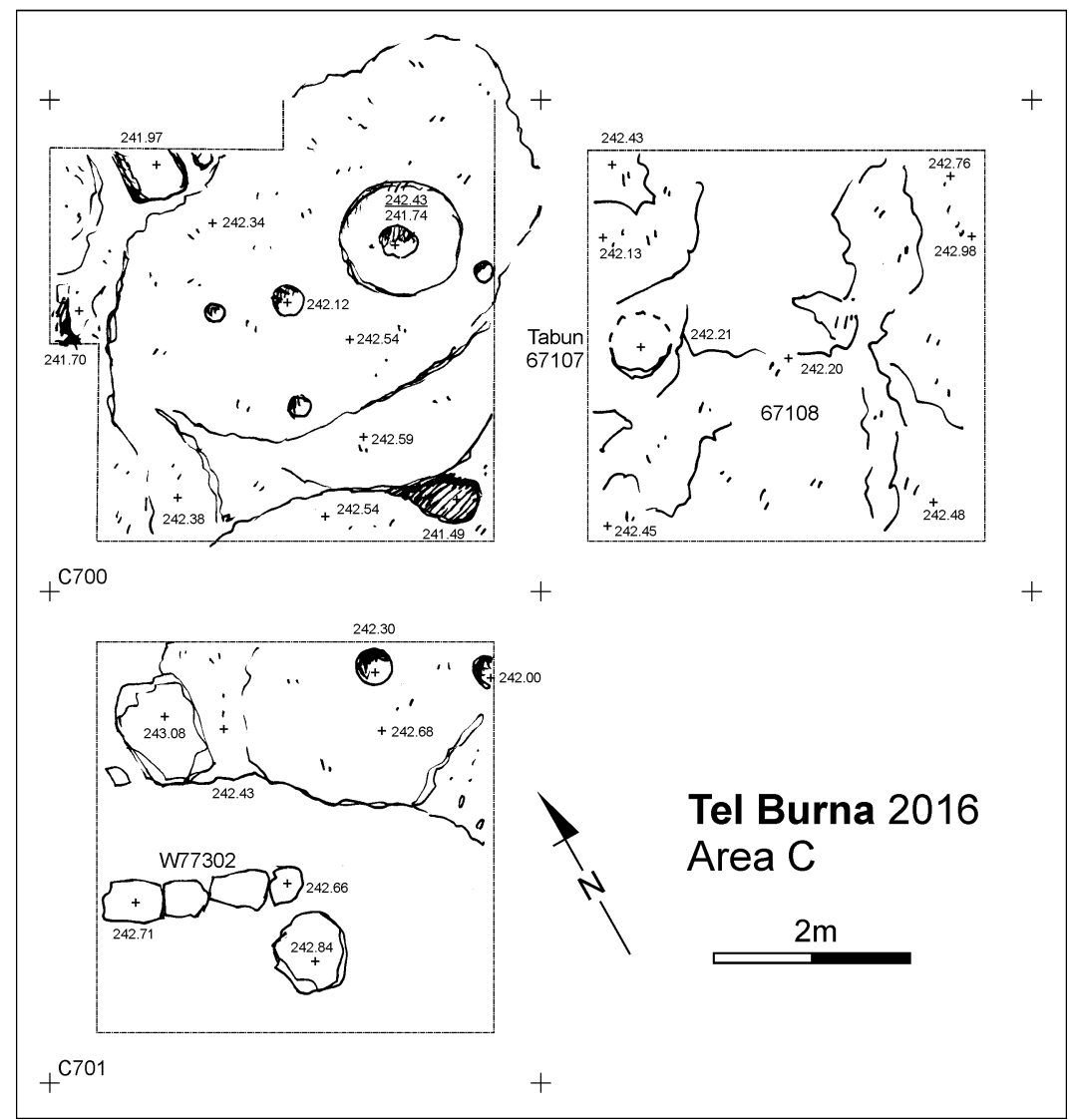

As some of the installations are on surface level, the excavated sediment was only a few centimeters thick. The four samples taken from this area therefore contained in all only 20 seeds with single finds of barley $(10 \%)$, cereals $(20 \%)$ cultivated legumes $(15 \%)$ and some wild species which were also found in the other areas of the tell like stoneseed, trefoil, wild grasses and Thymelaea sp. (Table 1).

\section{DISCUSSION}

\section{The Lathyrus sativus finds and their meaning}

The absence of archaeological finds and installations connected directly to agricultural activities in Area B1 is noteworthy. The storage find of grass pea seeds might be connected to the cultic activities of the complex in which food preparation and feasting would have played a major role (Shai et al., 2015: 116). The animal bones and drinking vessels from the courtyard support such activities, strengthening the interpretation of Building 29305 as cultic (Shai et al., 2015: 129).

Compared to cereals or lentils, finds of grass pea in the southern Levant are relatively rare in the archaeobotanical record (Riehl \& Kümmel, 2005). However, for the Late Bronze Age there are 
two other sites in the vicinity of Tel Burna in which a relatively high amount of grass pea seeds have been found.

At Tel Miqne-Ekron, about 600 seeds of Lathyrus sativus/cicera ${ }^{8}$ were stored in a locally made bowl. The bowl was found within a destruction layer (Stratum VIIIA) of Building 150 (Field I) located on the summit of the tell dating to the Late Bronze Age IIB (Mahler-Slasky \& Kislev, 2010: 2480-2481).

At Tel Batash, the grass pea seeds were also found in a layer of destruction debris (Stratum VIII) dating to the $15^{\text {th }}$ century B.C.E. This layer was located in Room 494 of Building 475 (Area B), interpreted as a Canaanite patrician house (Mazar, 1997: 252). The seeds were found in the entrance area to this building (Mahler-Slasky \& Kislev, 2010: 2480; Mazar, 1997: Fig. 15).

Unlike the finds from Tel Burna and Tel Miqne-Ekron, at Tel Batash only 60 seeds of Lathyrus sativus/cicera were found. However, the seeds also derive from only a single context similar to the contexts at Tel Burna and Tel Miqne-Ekron.

The grass pea in antiquity, as in modern times was preferably used as fodder, but it could also be used for human consumption. The growing conditions for Lathyrus sativus are less demanding than for other crops such as free threshing wheat or lentil (see Riehl, 2009: Table 1): the grass pea is more resistant to drought, it is quite resistant to pest infestation, and it can also grow in soils poor in nutrients. The seeds of the grass pea are extremely nutritious, however, they are toxic when consumed in high amounts (Mahler-Slasky \& Kislev, 2010: 2478-2479). This might also be the reason why Lathyrus sativus did not reach the high number of finds within the archaeobotanical record of the southern Levant (see Riehl \& Kümmel, 2005). Yet, cooking and soaking the seeds in water washes out the toxic amino acids, which cause lathyrism, a condition characterized by the loss of muscular control and paralysis of the lower limbs (Mahler-Slasky \& Kislev, 2010: 2479). According to Mahler-Slasky \& Kislev (2010: 2482) the cultivation of various Lathyrus-species including Lathyrus sativus have their origin in the Aegean and cultivation expanded to the southern Levant during the Middle Bronze Age. ${ }^{9}$

Tel Burna, Tel Batash, and Tel Miqne-Ekron in which comparatively high amounts of grass pea seeds have been found, are located in close proximity to one another. Like other important sites from the $13^{\text {th }}$ century B.C.E., the Late Bronze Age pottery from Tel Burna includes many imports from Mycenae and Cyprus (Shai et al., 2015: 117-119) indicating some sort of interconnections in the form of trade or otherwise with the Aegean. At both Tel Batash (Mahler-Slasky \& Kislev, 2010: 2480; Steel, 2006: 152-153) and Tel Miqne-Ekron (Meehl et al., 2006: 29) the remains of Mycenaean and Cypriot pottery and other prestige items were discovered, as well, indicating similar connections to the Aegean. Altogether, the evidence implies that either the grass pea finds were imported as merchandise from the Aegean or of some other affinity between these regions. It is also noteworthy that in all three sites, the grass pea seeds were discovered in elite or cultic contexts, which may be interpreted to reflect upon the consumption of the grass pea in the high-status social classes, or may imply their consumption as part of cultic activities in the Late Bronze Age and in this area.

\footnotetext{
8 "In archaeobotanical material it is not possible to distinguish between the seeds of [cultivated] L.[athyrus] sativus and those of the closely related [wild growing] L.[athyrus] cicera."(Mahler-Slasky \& Kislev, 2010: 2478). However, in this paper we are convinced that we found cultivated grass pea seeds which that is why we identify them as Lathyrus sativus.

${ }^{9}$ Ben-Shlomo et al. (2008: 235) mention that Lathyrus sativus was introduced to the southern Levant with the Philistines. However, the grass pea finds from Tel Batash $\left(15^{\text {th }}\right.$ century B.C.E., Kislev et al., 2006) clearly show that this plant is not a "new cultural element" (Ben Shlomo et al., 2008: 235) introduced in the early Iron Age. Rather we can see increased finds of grass pea seeds from the Late Bronze Age IIB (13 ${ }^{\text {th }}$ century B.C.E.; see Riehl \& Kümmel, 2005) in sites which are later connected to Philistine occupation.
} 
Orendi A., Smejda L., McKinny Ch., Cassuto D., Sharp C., Shai I.: The agricultural landscape of Tel Burna: ecology and economy of a Bronze Age/Iron Age settlement in the Southern Levant

Alternatively, the increased finds of grass pea seeds might also be the result of drier climatic conditions as Lathyrus sativus is more drought resistant than, for example, lentil. As mentioned above, the end of the Late Bronze Age was a period of drier conditions (Langgut et al., 2013: 160-61; Langgut et al., 2015: 229; Soto-Berelov et al., 2015: 107). Yet, the Dead Sea levels indicate that the dry period had already started with the beginning of the Late Bronze Age (Migowski et al., 2006: 426; Kagan et al., 2015: 247). The calculated paleo-rainfall by Bar-Matthews and Ayalon (2004: Figure 12) in contrast show an increased precipitation around $3300 \mathrm{BP}$.

\section{The other carbonized plant remains from the Late Bronze Age}

The remaining charred macro remains found in Area B1 may be the remnants of crop storage or of food processing (see van der Veen, 2007: 979), as supported by the two pithoi and the two ovens/tabuns. The high proportion of wild species seeds and the bad preservation of the macro remains may be explained by the proximity of this layer to the modern surface. Hence, the macro remains from wild plants, although charred, might be the result of modern contaminants. Darnel grass, trefoil, and wild grasses show a relatively high proportion and ubiquity within the archaeobotanical material from Area B1 (excluding the grass pea finds). The local flora of the southern Levant consists of hundreds of pasture plants including many wild grass species, e.g. darnel grasses, as well as about 30 species of trefoil (Zohary, 1962: 215). As nowadays the tell is used as a grazing rangeland, and was likely used as such through the ages, it is possible that the macro remains mentioned above are residues of the pasture plants from the tell which entered the archaeological sediments after the abandonment of the site by soil bioturbation.

\section{The Iron Age agriculture at Tel Burna}

The archaeobotanical as well as the archaeological data allow us to gain comprehensive insights into the agricultural landscape of Tel Burna. The macro remains from Areas A1, A2, and C represent the wide range of crop species, which were cultivated around and processed at Tel Burna. The archaeological installations as well as archaeological finds were connected either to food storage (silos) or to crop processing of secondary products (like wine/olive presses, loom weights).

The natural preconditions such as water supply and soil conditions were favorable for extensive agriculture in the area surrounding Tel Burna. The stable carbon isotopes indicate good water supply of barley grains during the Iron Age IIB and IIC which is also confirmed by the cultivation of demanding crops, such as flax which annually needs at least $400 \mathrm{~mm}$ of water during the growing season (Ertuğ, 2000: 176; Riehl, 2008: S48). The cultivation of various field crops found at Tel Burna (barley, wheat, lentil, bitter vetch, and flax) is not only attested by the archaeobotanical macro remains but also by the fact that they were found in the storage contexts of silos. Moreover, finds of typical field weeds such as darnel grass, pimpernel, cow cockle, and mallow (Zohary, 1962: 221-225) were directly associated with the seeds of cultigens within the same contexts and samples. The weed plants were harvested and processed together with the crops. After crop processing like threshing, winnowing and sieving, the crop material was stored still containing some impurities of weed seeds. The final cleaning of the cereal grains then took place directly before consumption (Hillman, 1984; 1985). In addition, the cultivation of flax is affirmed by the finds of dodder seeds, a parasite to flax plants (Feinbrun-Dothan, 1978: 41) within the same samples and contexts.

The archaeobotanical finds of cultigens are most probably relics of the crops processed at Tel Burna that were cultivated during winter months (Borowski, 1987: 32-38; Charles, 1985: Table 1). There are remains of crops known to be demanding crops, whether for water supply, e.g. lentil and flax (Riehl, 2009: Table 1), or for soil nutrients, e.g. flax (Kislev et al., 2011: 580). Other field 
crops like emmer wheat, barley, and bitter vetch show a high tolerance to drier conditions and saline soils (Riehl, 2009: Table 1). According to Riehl and Shai (2015: 531), precipitation in the region of Tel Burna was sufficient for rain-fed agriculture. Yet, shifts in annual rainfall might have led to irrigation when needed. The majority of macro remains were found in the silo contexts in which the crops would have been stored (van der Veen, 2007: 979).

Olive, grape, and fig are typical fruit cultigens of the southern Levant. The fig seeds were more numerous in the archaeobotanical record than olive or grape. Yet, the seeds per distribution unit is much higher than for olive or grape so that the high number of fig seeds might not correspond to a more extant cultivation of this plant (Riehl \& Shai, 2015: 531). Cultivation of olive trees and vineyards might have been possible, although both species need a higher amount of water supply (500-600 mm; Riehl, 2009: Table 1) than available by precipitation in the lower Shephelah. The regional distribution of ancient wine and olive presses, though, indicates that olive and grape cultivation extended into regions receiving less than $500 \mathrm{~mm}$ rainfall per year today (Riehl \& Shai, 2015: 529-530). The archaeological remains of olive and/or wine presses on the eastern spur of the tell suggest that olive orchards and vineyards had been maintained in the vicinity. So far, the samples from Area $\mathrm{C}$ have not contained any remains of the basic products, which would have been processed for olive oil or wine.

The discovery of loom weights found in situ, provide evidence for the warp-weighted loom and hence weaving activity in the courtyard in Area A2. ${ }^{10}$ The abundance of linseeds at the site may be interpreted in this context as evidence of flax cultivation for the production of linen textiles. However, it is just as likely that the warp-weighted looms were used for weaving woolen textiles and the linseeds used for consumption, for the production of linseed oil, or as seeds for subsequent sowing (Kislev et al., 2011: 582).

The agricultural activities during the Iron Age took place inside the fortified settlement and on the eastern slope of the tell directly outside the fortification. The archaeobotanical data alone cannot provide a full reconstruction of crop management at Iron Age Tel Burna. Yet, it is obvious from the archaeological remains that there was a shift in the settlement structure during the Iron Age IIC ( $7^{\text {th }}$ century B.C.E.) when the silos appear on the site. In fact, the samples from the silos provide the highest and the most diverse macro remains from Tel Burna. However, as most of the Iron Age samples were poor in seed and fruit remains it is difficult to attest a difference between the Iron Age IIA/B and IIC assemblage. An extended need for large-scale crop storage might be one reason for the construction of the silos. This might be connected to sociocultural changes in the Shephelah, possibly intensified trade with the Coastal Plain or increased tribute imposed on Judah after the military campaign of Sennacherib (Faust \& Weiss, 2005; Riehl \& Shai, 2015: 531-532).

Some of the most ubiquitous wild species found in the Iron Age samples grow as weeds. Dodder, darnel grass, cow cockle, and pimpernel might have been gathered with the field crops and entered the settlement in this way. Other wild taxa might have entered the archaeological contexts after the abandonment of the settlement growing on the ruins of the tell. The seeds of Lithospermum cf. tenuiflorum from Area A2 might have been stored plant remains. However, stoneseed remains show a high distribution throughout all areas excavated at Tel Burna, which would suggest these macro remains to be modern contaminants. Lithospermum tenuiflorum grows in batha habitats and on fallow fields within the eastern Mediterranean and western Irano-Turanian

\footnotetext{
10 Loom weights were also found inside the casemate wall in Area A1. It is worth noting that flax (pisteh) appears twice in the Samson narrative (Judg 13-16; cf. also Josh 2:6 [Jericho]; Prov 31:13; Isa 19:9; Hos 2:5, 9]), which is set in the Judean Shephelah and Hill Country. In both cases, flax is referenced in association with the production of "new ropes" (Judg 15:14; 16:9), which failed to bind Samson. The occurrence of flax in this narrative is a textual indicator that flax was commonly grown, harvested, and developed into products during the Biblical era.
} 
plantgeographical vegetation zone (Feinbrun-Dothan, 1978: 68). According to the Flora of Israel Online (Danin, 2003-2017) this plant rarely occurs in the Shephelah today, however this does not eliminate the possibility that it may be present at modern Tel Burna.

The archaeobotanical evidence, at least for the Iron Age II (Areas A1 and A2), demonstrates a thriving and diverse agricultural economy. The presence of numerous agricultural installations, the storage facilities, and the loom weights strengthen our understanding that Tel Burna was an active producer of agricultural primary and secondary products within the Shephelah, an area which has been established as the breadbasket of southern Canaan and, subsequently, the Kingdom of Judah (Riehl \& Shai, 2015: 525).

\section{CONCLUSION}

The macro remains from the Late Bronze Age (Area B1) show that the significance of archaeobotanical remains goes beyond their apparent significance as mere ecological and economic products. The discovery of the stored grass pea seeds and of imported pottery from Tel Burna, similarly at both Tel Miqne-Ekron and Tel Batash, attests to a form of connection or affinity with the Aegean. The macro remains from the Iron Age (Area A1, A2, and C) are the relics of an agricultural economy. The complexities of the agricultural landscape at Tel Burna can be further understood when the agricultural remains, as attested by the archaeobotanical finds of cultigens and field weeds, are combined with the archaeological evidence associated with different agricultural activities. Environmental preconditions in the lower Shephelah were more than sufficient for extensive field farming, cultivation of orchards, and vinification. The Iron Age macro remains reveal a broad spectrum of Mediterranean crops, however, no specialization in a particular crop species can be identified. The archaeological Iron Age remains indicate that the processing of secondary products such as olive oil, wine, or textiles took place within the Iron Age settlement or directly outside the fortification wall on the eastern side of the tell (in the vicinity of Area C). Future archaeobotanical analyses at Tel Burna may help to differentiate between the other sub-periods of the Iron Age, against the obvious change in the agricultural landscape from the $8^{\text {th }}$ to the $7^{\text {th }}$ century B.C.E..

\section{ACKNOWLEDGEMENTS}

We would like to acknowledge the following organizations for generously funding our research: The Tel Burna Archaeological Project and its staff and team members, Ariel University and the Department of Land of Israel Studies and Archaeology at Ariel University, the Israel Science Foundation [grant No. 522/16], the Deutsche Forschungsgemeinschaft, Tübingen University and the SFB 1070 "ResourceCultures" Project A05 and especially Prof. Jens Kamlah and PD Dr. Simone Riehl, project CIGA 20144207 (Czech University of Life Sciences Prague) and a host of colleagues and students without whose unstinting support this research would not have been successfully carried out.

\section{REFERENCES}

Bar-Matthews, M. \& Ayalon, A. (2004). Speleothems as Climate Indicators, a Case Study from Soreq Cave Located in the Eastern Mediterranean Region, Israel. In Battarbee, R. W., Gasse, F. \& Stickley, C. (Eds.) Past Climate Variability through Europe and Africa (pp. 363-391). Dordrecht: Kluwer Academic Publishers. 
Ben-Shlomo, D., Shai, I., Zukerman, A. \& Maeir, A. M. (2008). Cooking Identities: Aegean-Style Cooking Jugs and Cultural Interaction in Iron Age Philistia and Neighboring Regions. American Journal of Archaeology 112, 225-246.

Borowski, O. (1987). Agriculture in Iron Age Israel. Winona Lake, Indiana: Eisenbrauns.

Charles, M. P. (1985). An Introduction to the Legumes and Oil Pulses of Mesopotamia. Bulletin on Sumerian Agriculture II, 39-61.

Currid, J. D. (1984). The Deforestation of the Foothills of Palestine. Palestine Exploration Quarterly 116, 1-11.

Dan, J., Yaalon, D. H., Koyumdjisky, H. \& Raz, Z. (1976). The soils of Israel. Pamphlet 159. The Volcani Center, Bet Dagan, Israel: Ministry of Agriculture, Agricultural Research Organization Institute of Soils and Water, Soil Conservation and Drainage Department.

Danin, A. (2003-2017). Flora of Israel Online. Retrieved April, 23, 2017, from http://flora.org.il/en/plants/BUGTEN/.

David, B. \& Thomas, J. (2008). Landscape Archaeology: Introduction. In David, B. \& Thomas, J. (Eds.), Handbook of Landscape Archaeology (pp. 27-43). Walnut Creek, CA: Left Coast Press.

Dever, W. G. (2012). The Lives of Ordinary People in Ancient Israel: Where Archaeology and the Bible Intersect. Grand Rapids: Wm. B. Eerdmanns Publishing.

Ertuğ, F. (2000). Linseed Oil and Oil Mills in Central Turkey. Flax/Linum and Eruca, important oil plants in Anatolia. Anatolian Studies 50, 171-185.

Fairbairn, A. S. (2008). Beyond Economy: Seed Analysis in Landscape Archaeology. In David, B. \& Thomas, J. (Eds.), Handbook of Landscape Archaeology (pp. 442-450). Walnut Creek, CA: Left Coast Press.

Faust, A., \& Weiss, E. (2005). Judah, Philistia, and the Mediterranean World: reconstructing the economic system of the seventh century BCE. Bulletin of the American Schools of Oriental Research 338, 71-92.

Feinbrun-Dothan, N. (1978). Flora Palaestina. Part Three, Text. Jerusalem: The Israel of Sciences and Humanities.

Finkelstein, I. \& Na'aman, N. (2004). The Judahite Shephelah in the late 8th and early 7th centuries BCE. Tel Aviv 31(1), 60-79.

Grabbe, L. L. (2003). Like a Bird in a Cage: The Invasion of Sennacherib in 701 BCE. European Seminar in Historical Methodology 4. London, New York: Sheffield Academic Press.

Hardin, J. W. (2014). Judah during the Iron Age II Period. In Steiner, M. L. \& Killebrew, A. E. (Eds.), The Oxford Handbook of the Archaeology of the Levant c. 8000 - 332 BCE (pp. 743-756). Oxford: University Press.

Helbaek, H. (1958). Plant economy in ancient Lachish. In Tufnell, O., Lachish IV: The Bronze Age (pp. 309-317). London: Oxford University Press.

Hillman, G. (1984). Traditional Husbandry and Processing of Archaic Cereals in Recent Times: the Operations, Products and Equipment which might feature in Sumerian Texts. Part I: the Glume Wheats. Bulletin of Sumerian Agriculture Volume I, 114-151.

Hillman, G. (1985). Traditional Husbandry and Processing of Archaic Cereals in Recent Times: the Operations, Products and Equipment which might feature in Sumerian Texts. Part II: the Free-Threshing Cereals. Bulletin of Sumerian Agriculture Volume II, 1-31.

Jacomet, S. (2006). Bestimmung von Getreidefunden aus archäologischen Ausgrabungen. 2nd edn. Basel: IPNA. 
Orendi A., Smejda L., McKinny Ch., Cassuto D., Sharp C., Shai I.: The agricultural landscape of Tel Burna: ecology and economy of a Bronze Age/Iron Age settlement in the Southern Levant

Kagan, E. J., Langgut, D., Boaretto, E., Neumann, F. H. \& Stein, M. (2015). Dead Sea Levels During The Bronze And Iron Ages. Radiocarbon 57 (2), 237-252.

King, P. J. \& Stager, L. E. (2001). Life in Biblical Israel. Louisville: Westminster John Knox Press.

Kislev, M. E., Melamed, Y. \& Langsam, Y. (2006). Plant Remains from Tel Batash. In Panitz-Cohen, N. \& Mazar, A. (Eds.), Timnah (Tel Batash) III: The Finds from the Second Millennium BCE. Qedem 45 (pp. 295-310). Jerusalem: Hebrew University of Jerusalem.

Kislev, M. E., Simchoni, O., Melamed, Y. \& Maroz, L. (2011). Flax Seed Production: Evidence from the Early Iron Age Site of Tel Beth-Shean, Israel and from Written Sources. Vegetation History and Archaeobotany 20, 579-584.

Langgut, D., Finkelstein, I. \& Litt, T. (2013). Climate and Late Bronze Age Collapse: New Evidence from the Southern Levant. Tel Aviv 40, 149-175.

Langgut, D., Finkelstein, I., Litt, T., Neumann, F. H. \& Stein, M. (2015). Vegetation And Climate Changes During The Bronze And Iron Ages ( 3600-600 BCE) In The Southern Levant Based On Palynological Records. Radiocarbon 57 (2), 217-235.

Laustrup, M. \& Seger, J. D. (1990). Botanical remains from Tell Halif. Bulletin of the American Schools of Oriental Research Supplement 26, 23-24.

Liphschitz, N. (2004). The Archaeobotanical Remains. In Ussishkin, D., The renewed archaeological excavations at Lachish (1973-1994). Volume V (pp. 2230-2247). Tel Aviv: Tel Aviv University.

Liphschitz, N. \& Waisel, Y. (1975). Analysis of the botanical material. In Aharoni, Y., Lachish V. Investigations at Lachish. The sanctuary and the residency (pp. 104). Tel Aviv: Gateway.

Mahler-Slasky, Y. \& Kislev, M. E. (2010). Lathyrus consumption in late Bronze and iron age sites in Israel: an Aegean affinity. Journal of Archaeological Science 37, 2477-2485. DOI: 10.1016/j.jas.2010.05.008.

Mahler-Slasky, Y. \& Kislev, M. E. (2012). Preliminary Archaeobotanical Research at Tell es-Safi/Gath - The 1997-2002 Seasons. In Maeir, A. M. (Ed.), Tell es-Safi/Gath I: The 1996 2005 Seasons. Volume 1: Text (pp. 579-587). Wiesbaden: Harrassowitz Verlag.

Mazar, A. (1997). Timnah (Tel Batash) I. Stratigraphy and Architecture. Text. Qedem 37. Jerusalem: Keterpress Enterprises.

Meehl, M. W., Dothan, T. \& Gitin, S. (2006). Tel Miqne-Ekron Excavations 1995-1996. Field INE East Slope Iron Age I (Early Philistine Period). Tel Miqne-Ekron Final Field Reports Series No. 8. Jerusalem: Old City Press.

Migowski, C., Stein, M., Prasad, S., Negendank, J. F. W. \& Agnon, A. (2006). Holocene Climate Variability and Cultural Evolution in the Near East from the Dead Sea Sedimentary Record. Quaternary Research 66, 421-431.

Neef, R., Cappers, R. T. J. \& Bekker, R. M. (2011). Digital Atlas of Economic Plants in Archaeology. Groningen: Barkhuis.

Nesbitt, M. (2008). Identification Guide for Near Eastern Grass Seeds. London: Left Coast Pr Inc.

Neumann, F. H., Kagan, E. J., Schwab, M. J. \& Stein, M. (2007). Palynology, Sedimentology and Palaeoecology of the Late Holocene Dead Sea. Quaternary Science Reviews 26, 1476-1498.

Olsvig-Whittaker, L., Maier, A. M., Weiss, E., Frumin, S., Ackermann, O. \& Kolska Horwitz, L. (2015). Ecology of the Past - Late Bronze and Iron Age Landscapes, People and Climate Change in Philistia (the Southern Coastal Plain and Shephelah), Israel. Journal of Mediterranean Ecology 
$13,57-75$.

Pustovoytov, K. \& Riehl, S. (2006). Suitability of biogenic carbonate of Lithospermum fruits for ${ }^{14} \mathrm{C}$ dating. Quaternary Research 65, 508-518.

Rambeau, C. M. C. (2010). Palaeoenvironmental reconstruction in the Southern Levant: synthesis, challenges, recent developments and perspectives. Philosophical Transactions of Royal Society A $368,5225-5248$.

Riehl, S. (2008). Climate and Agriculture in the Ancient Near East: a Synthesis of the Archaeobotanical and stable carbon Isotope evidence. Vegetation History and Archaeobotany 17, Supplement 1, S43-S51.

Riehl, S. (2009). Archaeobotanical evidence for the interrelationship of agricultural decision-making and climate change in the ancient Near East. Quaternary International 197, 93-114. DOI: http://dx.doi.org/10.1016/j.quaint.2007.08.005

Riehl, S. (2010). Plant Production in a Changing Environment: The Archaeobotanical Remains from Tell Mozan. In Deckers, K., Doll, M., Pfälzner, P. \& Riehl, S. (Eds.) Development of the Environment, Subsistence and Settlement of the City of Urkeš and its Region. Studien zur Urbanisierung Nordmesopotamiens Serie A. Ausgrabungen 1998-2001 in der Zentralen Oberstadt von Tall Mozan/Urkeš (pp. 13-158). Wiesbaden: Harrassowitz Verlag.

Riehl, S. \& Kümmel, C. (2005). Archaeobotanical Database of Eastern Mediterranean and Near Eastern Sites. Retrieved April, 23, 2017, from http://www.ademnes.de/index.php.

Riehl, S. \& Shai, I. (2015). Supra-regional trade networks and the economic potential of Iron Age II sites in the Southern Levant. Journal of Archaeological Science: Reports 3, 525-533. DOI: http://dx.doi.org/10.1016/j.jasrep.2015.08.004.

Rosen, A. (1986). Quaternary alluvial stratigraphy of the Shephela and its paleoclimate implications. Jerusalem: Geological Survey of Israel.

Salavert, A. (2008). Olive Cultivation and Oil Production in Palestine during the Early Bronze Age (3500 - 2000 B.C.): the Case of Tel Yarmouth, Israel. Vegetation History and Archaeobotany 17, Supplement 1, S53-S61.

Shai, I. (2017). Tel Burna - A Judahite Fortified Town in the Shephelah. In Lipschits, O. \& Maeir, A. M. (Eds.) “...as plentiful as sycamore-fig trees in the Shephelah” (I Kings 10:2) Recent Archaeological Research in the Shephelah of Judah: The Iron Age, (pp. 45-60). Winona Lake, Indiana: Eisenbrauns.

Shai, I. \& Uziel, J. (2014). Addressing Survey Methodology in the Southern Levant: Applying Different Methods for the Survey of Tel Burna. Israel Exploration Journal 64, 172-190.

Shai, I., Cassuto, D., Dagan, A. \& Uziel, J. (2012). The Fortifications at Tel Buran: Date, Function and Meaning. Israel Exploration Journal 62 (2), 141-157.

Shai, I., McKinny, C. \& Uziel, J. (2015). Late Bronze Age Cultic Activity in Ancient Canaan: A View from Tel Burna. Bulletin of the American Schools of Oriental Research 374, 115-133.

Sharp, C., McKinny, C. \& Shai, I. (2015). The Late Bronze Age Figurines from Tel Burna. Strata: Bulletin of the Anglo-Israel Archaeological Society 33, 61-75.

Smejda, L., Hejcman, M., Horak, J. \& Shai, I. (2017). Ancient settlement activities as important sources of nutrients $(\mathrm{P}, \mathrm{K}, \mathrm{S}, \mathrm{Zn}$ and $\mathrm{Cu})$ in Eastern Mediterranean ecosystems - The case of biblical Tel Burna, Israel. Catena 156, 62-73. DOI: http://dx.doi.org/10.1016/ j.catena.2017.03.024.

Soto-Berelov, M., Fall, P. L., Falconer, St. E. \& Ridder, E. (2015). Modeling Vegetation Dynamics in the Southern Levant through the Bronze Age. Journal of Archaeological Science 53, 
94-109.

Steel, L. (2006). Cypriot and Mycenaean Pottery. In Panitz-Cohen, N. \& Mazar, A. (Eds.), Timnah (Tel Batash) III: The Finds from the Second Millennium BCE. Qedem 45 (pp. 151-172). Jerusalem: Old City Press.

Ussishkin, D. (1977). The Destruction of Lachish by Sennacherib and the Dating of the Royal Judean Storage Jars. Tel Aviv 4 (1-2), 28-60.

Ussishkin, D. (2006). Sennacherib's Campaign to Philistia and Judah: Ekron, Lachish, and Jerusalem. In Amit, Y., Ben Zvi, E., Finkelstein, I. \& Lipschitzs, O. (Eds.) Essays on Ancient Israel in Its Near Eastern Context: A Tribute to Nadav Na'aman (pp. 338-357). Winona Lake, Indiana: Eisenbrauns.

Uziel, J. \& Shai, I. (2010). The Settlement History of Tel Burna: Results of the Surface Survey. Tel Aviv 37, 227-245.

van der Veen, M. (2007). Formation processes of desiccated and carbonized plant remains - the identification of routine practice. Journal of Archaeological Science 34, 968-990. DOI: 10.1016/j.jas.2006.09.007.

Weiss, E. (2011). Plant Remains. In Faust, A. \& Ehrlich, A. (Eds.), The Excavations of Khirbet er-Rasm, Israel. The changing Faces of the Countryside. BAR International Series 2187 (pp. 166-167). Oxford: Archaeopress.

Weiss, E., Kislev, M. E. \& Mahler-Slasky, Y. (2011). Plant Remains. In Stager, L. E., Master, D. M. \& Schloen, J. D. (Eds.), Ashkelon 3. The Seventh Century B.C. Harvard Semitic Museum Publications (pp. 591-613). Winona Lake, Indiana: Eisenbrauns.

Zohary, M. (1962). Plant Life of Palestine. New York: Ronald Press Company.

Zwickel, W. (2013). Leben und Arbeit in biblischer Zeit. Eine Kulturgeschichte. Stuttgart: Calwer Verlag. 